\title{
Equatorial Submergence in a Solitary Coral, Balanophyllia elegans, and the Critical Life Stage Excluding the Species from Shallow Water in the South
}

\author{
T. Gerrodette \\ Scripps Institution of Oceanography, University of California, La Jolla, California 92093, USA
}

\begin{abstract}
The geographic and bathymetric distributions of a solitary coral, Balanophyllia elegans, were studied, especially in the southern part of its range. This species is an example of equatorial submergence, occurring intertidally and subtidally in the north (Vancouver Island, Canada, to Point Conception, California), but subtidally only in the south (Point Conception to northern Baja California, Mexico). The absence of $B$. elegans from depths less than $10 \mathrm{~m}$ in the south was investigated to identify the life history stages most sensitive to environmental factors, particularly temperature, in shallow water Newly settled and adult individuals were transplanted to buoys in the top few meters of water The transplanted adults grew more slowly than controls, but survived well and reproduced; moreover, planula larvae released by the transplanted adults successfully settled nearby under shallow-water conditions. Thus neither very early nor relatively late stages in the life history appeared critical in excluding $B$. elegans from shallow water. The critical period was the juvenile stage, since newly settled individuals showed poor survival after transplantation to buoys in shallow water. Distribution and mortality patterns were correlated with the temperature of the seawater. However, it is difficult to establish a simple causal relationship between high temperature and equatorial submergence, since subtidal temperature patterns are complex and since temperature may have many indirect but important effects.
\end{abstract}

\section{INTRODUCTION}

To inhabit a particular location, the members of a species must carry out the critical functions of gamete production, fertilization, embryological development, growth and, in many species, metamorphosis through one or more juvenile forms. The failure of even one of these functions will preclude the occurrence of that species (unless there is persistent immigration from other populations). In evaluating the effects of an environmental factor such as temperature on the distribution of a species, therefore, it is important to test the effects of the factor for all stages in the life history. Most studies concentrate on a single stage.

The solitary scleractinian coral Balanophyllia elegans Verrill lives in shallow, temperate waters off the west coast of North America from southern Canada to northern Mexico (Fig. 1). The present study reexamines and extends the geographic and bathymetric distribution of $B$. elegans and shows it to be an example of equatorial submergence. Although $B$. elegans is found both intertidally and subtidally in the northern part of its range, it occurs only at depths greater than
$10 \mathrm{~m}$ in the south. The chief purpose of the present investigation was to identify the life history stage(s) most sensitive to factors excluding the corals from shallow water (less than $10 \mathrm{~m}$ in depth) in the south. Three hypotheses, not mutually exclusive, were examined: first, that adult corals cannot survive, grow, and/or reproduce in shallow water; second, that larvae cannot survive, attach, and/or undergo metamorphosis in shallow water; and third, that juvenile corals cannot survive and/or grow in shallow water.

\section{MATERIAIS AND METHODS}

Information on the geographic and bathymetric distributions of Balanophyllia elegans was compiled from literature and from personal observations made intertidally and subtidally along the coast of California, U.S.A. and Baja California, Mexico. Individuals of $B$. elegans collected from the southern end of the species' range have been deposited in the Scripps Institution of Oceanography Invertebrate Collection.

Coral density was measured along a depth transect 


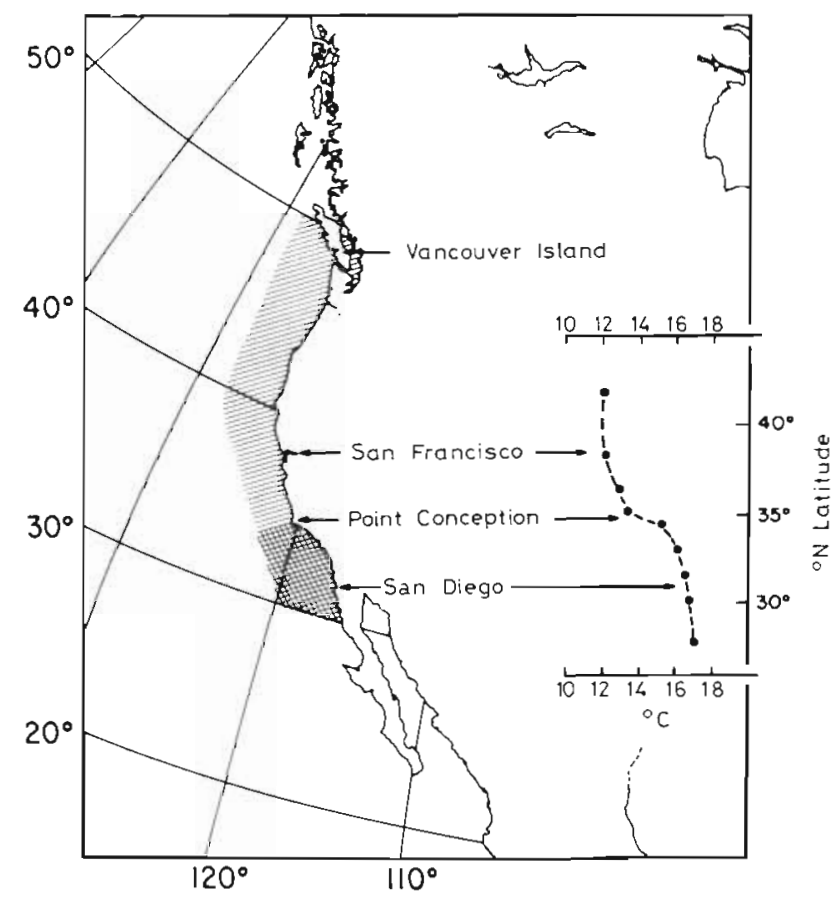

Fig. 1. Balanophyllia elegans. Range and equatorial submergence. Throughout most of its range, $B$. elegans may be found intertidally as well as subtidally (single hatching), but at the southern end of its range it is subtidal only (cross hatching). The graph of mean sea surface temperature, taken from Newman (in press), shows that submergence occurs near a steepening of the temperature gradient

in the kelp bed off Pt. Loma, San Diego, California. Individuals of Balanophyllia elegans used in field experiments were collected at a depth of $19 \mathrm{~m}$ below datum on a large rock outcrop known locally as Quast Rock, located $2.3 \mathrm{~km}$ southwest of the pier at Scripps Institution of Oceanography, La Jolla, California. Corals were transplanted into shallow water to a depth of $3 \mathrm{~m}$ below datum on a reef $3.1 \mathrm{~km}$ southwest of the pier or on subsurface buoys located approximately $200 \mathrm{~m}$ southwest of the end of the pier. Coral transplants to deeper water $(35 \mathrm{~m})$ were made in the La Jolla Submarine Canyon at a site known locally as the Cod Hole, $1.8 \mathrm{~km}$ southwest of the pier. Controls for these transplant experiments were placed at Quast Rock at a depth of $19 \mathrm{~m}$.

For transplantation adult corals were carefully collected with a spatula, taken to the laboratory, examined for any damage, and weighed. Each coral polyp was attached to a polyvinyl chloride (PVC) transplant plate $(27 \times 19 \mathrm{~cm})$ by a short section of PVC pipe with 3 stainless steel screws projecting into the lumen (Fig. 2). The screws acted as a clamp when tightened on the column of the coral polyp. Transplant plates with attached corals were secured in the field to construction blocks filled with concrete or to bolts set into rocks with epoxy. Transplant plates were also attached to subsurface buoys. A pipe on the taut buoy line contained projecting bolts to which the plates were attached vertically $3 \mathrm{~m}$ below the surface.

Coral growth was measured by weighing corals on a Roller-Smith balance to the nearest $0.002 \mathrm{~g}$ with the weighing pan hanging in a small container of seawater. The weight thus recorded was due to parts of the coral exceeding seawater in density. Most of the weight $(93.1 \%$ a mean of 12 values) was due to the calcium carbonate skeleton. Each coral was weighed 3 times before and after the experimental period, and the mean difference between the weighings was a measure of growth during the experimental period.

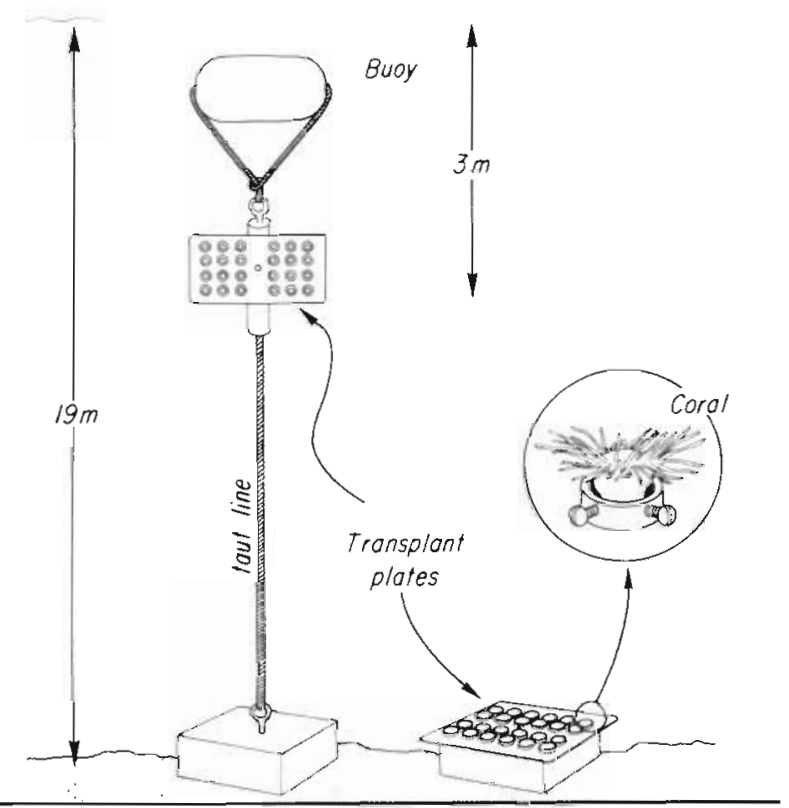

Fig. 2. Balanophyllia elegans. Methods of transplanting corals. Each polyp was held on a transplant plate by 3 small set screws. Transplant plates were attached to concrete blocks or to a line from a subsurface buoy

Corals in feeding experiments were each given a small piece of foot muscle of abalone (Haliotis rufescens) once every 2 weeks. To insure uniformity, a cork borer was used to cut small pieces $(3 \mathrm{~mm}$ in diameter, $1 \mathrm{~mm}$ thick) out of thin sections of abalone cut on a meat slicer. The small pieces were frozen until ready to use. Plates on the buoy were brought into the laboratory for feeding and later returned to the field; unfed controls were treated similarly.

Continuous subtidal temperatures at Quast Rock were recorded with a Ryan thermograph, Model F-8. Surface water temperatures were taken daily with a mercury thermometer off the end of the Scripps pier (SIO References 78-5 and 78-16). Long-term temperature records were extracted from National Ocean Survey $(1970)$. Laboratory experiments used the filtered 
seawater of the aquarium system at either chilled $\left(10^{\circ} \mathrm{C}\right.$ ) or ambient (surface) temperatures.

Corals used in upper lethal temperature experiments were acclimated for 6 weeks in running seawater between $16^{\circ}$ and $20^{\circ} \mathrm{C}$. These corals were divided into 4 groups of 17 individuals, and each group was exposed to an experimental temperature $\left(20^{\circ}, 25^{\circ}, 30^{\circ}\right.$, or $35^{\circ}, \pm$ $0.5 \mathrm{C}^{\circ}$ ) in well aerated water for $6 \mathrm{~h}$. After exposure, all corals were returned to running seawater at ambient temperature. Survival was recorded one week later.

Larvae were obtained by placing adult corals in a container of slowly running, chilled $\left(10^{\circ} \mathrm{C}\right)$ seawater. Small numbers of planulae would be released over a period of several weeks. These larvae settled on plates in the laboratory and underwent metamorphosis into juveniles. Another method of obtaining juveniles was to set out concrete-asbestos plates among adults in the field. After 6-12 months these plates usually contained some young corals.

\section{RESULTS}

\section{Range and Equatorial Submergence}

The northern limit of Balanophyllia elegans reported by Durham (1947) is $50^{\circ} \mathrm{N}$ latitude (Fig. 1). According to Durham and Barnard (1952), the species occurs southward to Pt. Conception and on the Channel Islands in the Southern California Bight. Turner et al. (1968) extended the range to the south by reporting $B$. elegans in the kelp bed at Pt. Loma, San Diego, California. I have observed this species in nearshore areas off San Diego, abundantly on Tanner and Cortes Banks west of San Diego (Wolfson et al., 1978), and southward along the coast of Baja California, Mexico, as far as Sacramento Reef (latitude $29^{\circ} 44^{\prime} \mathrm{N}$ ). I did not find $B$. elegans on Cedros Island $\left(28^{\circ} 15^{\prime} \mathrm{N}\right)$ where another species, B. cedrosensis, is reported from deeper water in Durham and Barnard (1952), nor on the San Benito

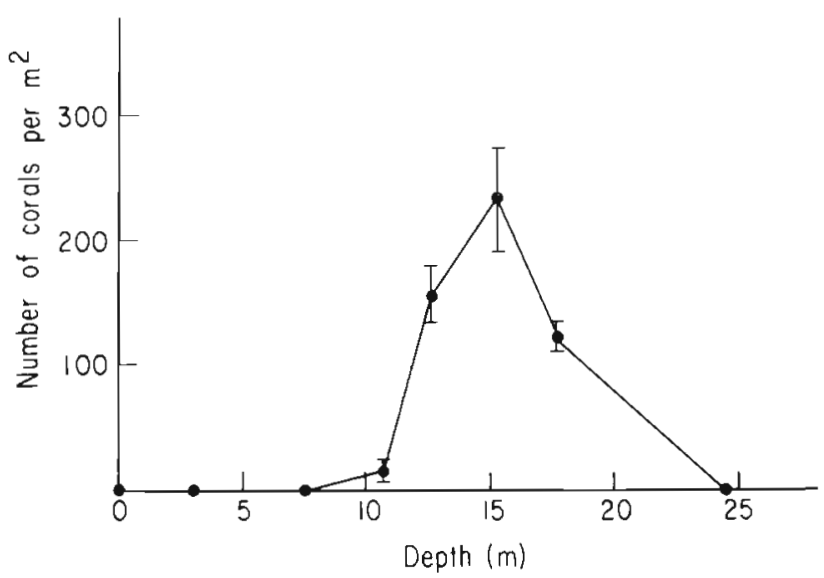

Fig. 3. Balanophyllia elegans. Density along a depth transect at Pt. Loma, San Diego, California. Each point is the mean of three $10 \times 1$-m belt transects; vertical bars indicate standard error

Islands $\left(28^{\circ} 20^{\prime} \mathrm{N}\right)$, despite a number of dives as deep as $42 \mathrm{~m}$ searching for them. These records constitute a southern range extension for $B$. elegans.

In the northern part of its range to approximately as far south as Pt. Conception $\left(35^{\circ} 26^{\prime} \mathrm{N}\right)$, Balanophyllia elegans occurs in the shallow subtidal and extends into the intertidal zone (Kozloff, 1973; Smith and Cariton, 1975; Fig. 1). In the San Diego area, near the southern end of its range, $B$. elegans is typically abundant at depths of 15-20 m, but rare or absent shallower than 10 m (Fig. 3); my abservations suggest that this absence in shallow water holds throughout southern California, U.S.A. and Baja California, Mexico. In Figure 3, the density of $B$. elegans also falls dramatically at the outer edge of the kelp bed at Pt. Loma at a depth of about $25 \mathrm{~m}$. The reasons for this decline are not understood, but it is probably a local phenomenon since $B$. elegans has been reported as deep as $587 \mathrm{~m}$ elsewhere (Durham and Barnard, 1952). At about $25 \mathrm{~m}$ the bottom at Pt. Loma drops abruptly at the 'sea cliffs', an ancient shoreline.

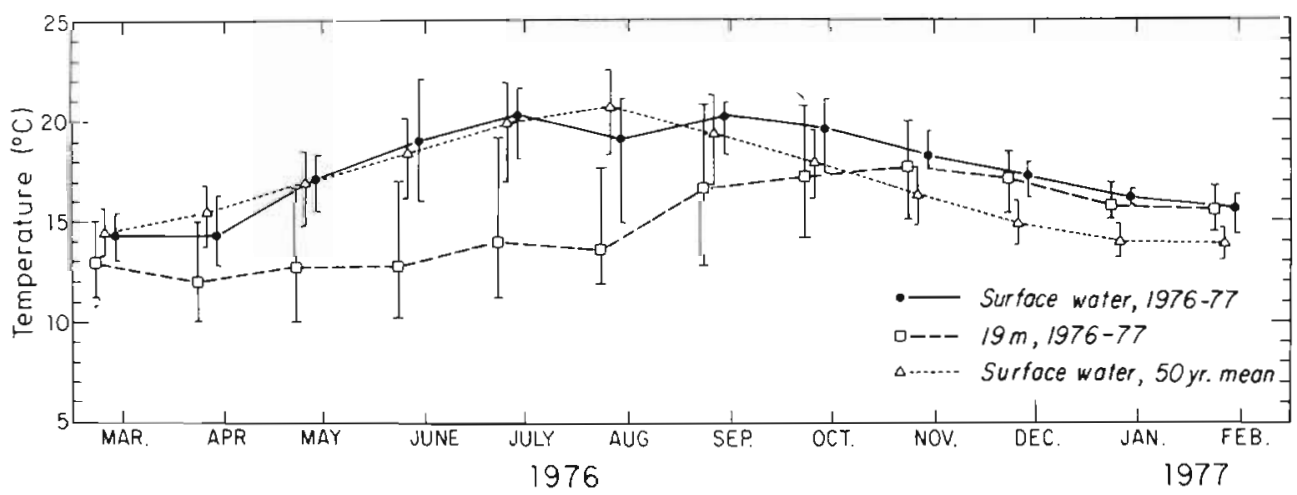

Fig. 4. Monthly means and ranges of surface and bottom (Quast Rock, $19 \mathrm{~m}$ depth) ocean water temperatures at La Jolla, California, from March, 1976 to February, 1977. Long-term temperature records were taken from National Ocean Survey (1970) and cover the years 1920-1969 


\section{Temperature}

At Quast Rock monthly mean subtidal temperatures at $19 \mathrm{~m}$ were consistently below surface temperatures at the nearby Scripps pier (Fig. 4). The maximum temperature recorded at $19 \mathrm{~m}$ exceeded the maximum temperature at the surface in certain months (November-February), but this was probably an artifact of continuous, rather than once daily, subtidal recording. The monthly ranges of temperature at $19 \mathrm{~m}$ were quite large in some months, but this is consistent with previous measurements showing considerable subtidal fluctuations in temperature (Clarke, 1968; Grigg, 1970; Scanland, 1971: Tutschulte, 1976).

During the late fall and winter, turbulence caused by storms creates a nearly isothermal water column. Under these conditions there is little or no difference in temperature between surface and $19 \mathrm{~m}$ and the range of temperatures is small (Fig. 4). From late spring to early fall, on the other hand, when storms are less frequent and insolation is increased, a strong thermocline often becomes established. Stratification of the water column leads initially to lower bottom temperatures, since the colder bottom water is not mixed with the overlying warmer water. This may account for the rather surprising fact that, at a depth of $19 \mathrm{~m}$, it may be colder in June than in January (see Fig. 4).

Stratification is also associated with internal waves, which travel along the thermocline. As such a wave passes a particular location, it is felt as a rapid change in temperature (Arthur, 1954; Quast, 1971). Large and rapid (up to $5{ }^{\circ} \mathrm{C}$ in less than an hour) fluctuations in temperature occurred at $19 \mathrm{~m}$ (Fig. 5). The fluctuations have approximately a 12 -h period, consistent with previous observations that show a strong tidal influence on temperature variations in shallow water (Defant, 1950; Leipper, 1950). Longshore and onshore currents also characteristically have a tidal frequency (Winant and Olson, 1976; Winant, 1979), and the temperature at $19 \mathrm{~m}$ is probably influenced by these water movements. Whatever the cause, marine organisms living at Quast Rock or other subtidal environments must be able to withstand large fluctuations in temperature over short periods of time.

\section{Transplant Experiments}

The possibility that adults of Balanophyllia elegans are not able to survive in shallow water was tested by transplanting them there. Adult corals survived in shallow water for over a year, as did the controls (Table 1). Most of the transplanted corals were on the buoy, since nearly all transplant plates attached to rocks in shallow water were either torn loose by waves or removed by curious sport divers (Plates \#2, 3,8 and 9). Even among the plates recovered, many corals fell out of their holders and were lost.

Although all retrieved corals, both shallow-water transplants and controls, were alive, the color and consistency of the soft tissue of the transplants made them appear less healthy. This subjective impression was supported by growth data. The mean annual increase among transplanted corals was only $1.0 \%$ $(\mathrm{N}=15)$, while controls at Quast Rock increased $10.0 \%$ in weight $(\mathrm{N}=30)$, a significantly greater growth rate ( $\mathrm{p}<0.036$, rank-sum test, two-tailed). These growth data include some corals not listed in Table 1, but exclude corals with pieces of the skeleton obviously broken off

Supplemental feeding of corals increased the growth rate. Corals fed biweekly on the buoy on Plate \#12 grew significantly more than unfed corals on Plate \# 11 ( $\mathrm{p}<0.01$, rank-sum test, one-tailed). The mean

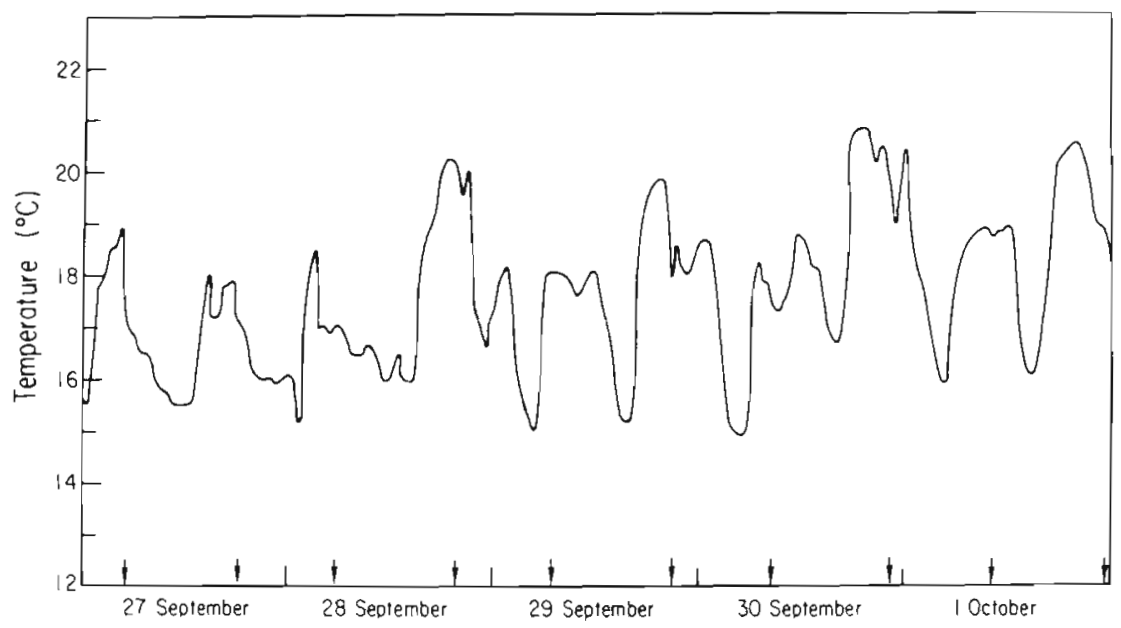

Fig. 5. A 5-day continuous thermograph record at Quast Rock (19 $\mathrm{m}$ depth; 1976), showing the rapid changes in temperature that may occur when a thermocline is present. Arrows indicate times of low tides 
annual increase in weight of the fed corals on Plate \# $12(12.2 \%)$ was close to the growth rate of control corals at Quast Rock (10.0\%), suggesting that adult corals on the buoy lacked food. The unfed control corals on Plate \# 11 actually lost weight (4.9\%). A similar result was obtained in the laboratory in chilled $\left(10^{\circ} \mathrm{C}\right)$ water. The weight of fed corals on Plate \# 14 increased $2.7 \%$, whereas the weight of unfed ones on Plate \# 15 decreased $1.3 \%$ on an annual basis. The difference is again statistically significant $(p<0.01$, rank-sum test, one-tailed). Loss of weight could be due to loss of soft tissue and/or loss of carbonate skeleton by breakage or resorption.

In spite of low growth rates, the corals transplanted into surface water were reproductive (females were carrying eggs or larvae). In addition, corals on Plates \# 17 and $A$, kept in the laboratory in surface-temperature or chilled water, were also fertile, releasing planulae which settled on sea tables in the laboratory.

The hypothesis that adult Balanophyllia elegans cannot survive, grow, and reproduce in shallow water was thus partially negated by the results of the adult transplant experiments. Adult corals transplanted into shallow water on buoys survived and were fertile, but growth was very slow. In particular, temperature did not seem to be critical for the survival of the adults, since temperatures exceeded the long-term mean during late 1976 and early 1977 when the transplant experiments were being run (Fig. 4). Further evidence against temperature was provided by the results of the lethal temperature determination. Survival of adults of $B$. elegans was high $(16 / 17)$ at $20^{\circ}$ and $25^{\circ} \mathrm{C}$, but all corals died at temperatures of $30^{\circ}$ or $35^{\circ} \mathrm{C}$. The lethal temperature for a 6 -h exposure therefore lies between $25^{\circ}$ and $30^{\circ} \mathrm{C}$. Corals in this experiment were not gradually acclimated to higher temperature. If, as is likely, some degree of acclimation is possible, the lethal temperature will be even higher. As shown in Figure 4, however, surface water temperatures are always well below $25^{\circ} \mathrm{C}$ even during the summer months at La Jolla. The maximum temperature during the warmest month, August, is $22.5^{\circ} \mathrm{C}$ (50-year mean). Temperature, therefore, does not directly exclude the adults of $B$. elegans from shallow water.

The hypothesis that planula larvae are not able to survive and undergo metamorphosis in shallow water was negated by laboratory observations. Planulae released from corals on transplant plates, as well as the planulae obtained from freshly collected corals, attached and underwent normal metamorphosis in the laboratory in surface-temperature water. This sequence was observed a number of times; in fact, settlement at $16^{\circ} \mathrm{C}$ was not statistically different from settlement at $10^{\circ} \mathrm{C}$ (Gerrodette, 1979). Of course, conditions may differ between field and laboratory, but, on the basis of laboratory observations, it seems reasonable to assume that planulae would be able to metamorphose in shallow water in the field also. Warm water at least does not prevent them from doing so.

Results of the juvenile transplant experiments were quite different from those of the adult (Table 2). Three experimental series of transplants were run. Experiment \# 1 had only a few juvenile corals that had settled on plates in the kelp bed at Pt. Loma in early 1976, but a higher mortality among juveniles on the buoy than at Quast Rock was suggested. In early 1977 a larger number of planulae settled on plates in the laboratory and these were used in Experiment \# 2 .

Table 1. Balanophyllia elegans. Results of adult transplant experiments. All corals were collected at Quast Rock. See text for description of locations and transplant methods

\begin{tabular}{|c|c|c|c|c|c|c|c|}
\hline \multirow[b]{2}{*}{ Plate } & \multirow[b]{2}{*}{ Treatment } & \multirow[b]{2}{*}{ Location } & \multirow[b]{2}{*}{ Depth $(m)$} & \multirow[b]{2}{*}{ Dates } & \multicolumn{3}{|c|}{ Number of corals } \\
\hline & & & & & Alive & Dead & Total" \\
\hline \# 1 & Shallow transplant & Casa Reef & 3 & 25 Aug. 76- Aug.77 & 2 & 0 & 2 \\
\hline \# 7 & Shallow transplant & Buoy & 3 & 29 Jan. $76-4$ Feb. 77 & 8 & 0 & 8 \\
\hline \#10 & Shallow transplant & Buoy & 3 & 11 Sept. $76-4$ Feb. 77 & 6 & 0 & 6 \\
\hline \#11 & Shallow transplant & Buoy & 3 & 23 Aug. $76-4$ Feb. 77 & 8 & 0 & 8 \\
\hline \# 12 & Shallow transplant & Buoy & 3 & 23 Aug. $76-4$ Feb. 77 & 10 & 0 & 10 \\
\hline \# 6 & Deep transplant & Cod Hole & 35 & 29 Jan. $76-7$ Mar. 77 & 8 & 0 & 8 \\
\hline \# 4 & Control & Quast Rock & 19 & 14 Oct. $75-12$ Feb. 77 & 6 & 0 & 6 \\
\hline \# 5 & Control & Quast Rock & 19 & 29 Jan. $76-12$ Feb. 77 & 6 & 0 & 6 \\
\hline \# 13 & Control & Quast Rock & 19 & 23 Aug. $76-12$ Feb. 77 & 8 & 0 & 8 \\
\hline \# 14 & Chilled water & Laboratory & - & 14 Aug. $76-30$ Dec. 76 & 12 & 0 & 12 \\
\hline \# 15 & Chilled water & Laboratory & - & 14 Aug. $76-30$ Dec. 76 & 12 & 0 & 12 \\
\hline \# 16 & Surface water & Laboratory & - & 14 Aug. $76-1$ Feb. 77 & 8 & 4 & 12 \\
\hline$\# 17$ & Surface water & Laboratory & - & 14 Aug. $76-1$ Feb. 77 & 11 & 1 & 12 \\
\hline$\# \mathrm{~A}$ & Chilled water & Laboratory & - & 8 July $75-17$ Nov. 76 & 12 & 0 & 12 \\
\hline
\end{tabular}


Table 2. Balanophyllia elegans. Results of juvenile transplant experiments. Juvenile corals that had settled on plates in the field or in the laboratory were moved to the locations shown. The number of plates in each treatment is listed in parentheses

\begin{tabular}{|c|c|c|c|c|c|c|c|}
\hline & \multirow[b]{2}{*}{ Treatment } & \multirow[b]{2}{*}{ Location } & \multirow[b]{2}{*}{ Depth (m) } & \multirow[b]{2}{*}{ Dates } & \multicolumn{3}{|c|}{ Number of corals } \\
\hline & & & & & Alive & Dead & Total \\
\hline \multirow{2}{*}{$\begin{array}{c}\text { Experiment } \\
\# 1\end{array}$} & Shallow transplant (2) & Buoy & 3 & 12 Aug. $76-9$ Oct. 76 & 0 & 5 & 5 \\
\hline & Control (1) & Quast Rock & 19 & 12 Aug. $76-9$ Oct. 76 & 3 & 1 & 4 \\
\hline \multirow{4}{*}{$\begin{array}{l}\text { Experiment } \\
\quad \# 2\end{array}$} & Shallow transplant (1) & Buoy & 3 & 2 May $77-20$ Sept. 77 & 0 & 23 & 23 \\
\hline & Control $(3)$ & Quast Rock & 19 & 2 May $77-26$ Sept. 77 & 30 & 18 & 48 \\
\hline & Surface water (4) & Laboratory & - & 8 May $77-23$ June 77 & 4 & 9 & 13 \\
\hline & Surface water (4) & Laboratory & - & 8 May $77-20$ Sept. 77 & 0 & 21 & 21 \\
\hline \multirow{3}{*}{$\begin{array}{c}\text { Experiment } \\
\# 3\end{array}$} & Shallow transplant $(2)$ & Buoy & 3 & 15 Jun. $77-20$ Sept. 77 & 91 & 21 & 112 \\
\hline & Control (1) & Quast Rock & 19 & 15 Jun. $77-26$ Sept. 77 & 115 & 4 & 119 \\
\hline & Surface water $(1)$ & Laboratory & - & 15 Jun. $77-20$ Sept. 77 & 147 & 60 & 207 \\
\hline
\end{tabular}

After $4 \frac{1}{2}$ months, all 23 juvenile corals placed in shallow water on the buoy were dead, while only 18 of 48 control corals at Quast Rock had died. A still larger number of juvenile corals for Experiment \# 3 were obtained by settlement on plates placed among adult Balanophyllia elegans on Tanner Bank, an offshore submarine bank $180 \mathrm{~km}$ west of San Diego. Plates were left on Tanner Bank in October, 1976 and retrieved in late May, 1977. When placed off Scripps for 3 months, mortality was $21 / 112=18.8 \%$ among the shallow transplants and $4 / 119=3.4 \%$ among the controls. For Experiments \#2 and \#3, a $\chi^{2}$ comparison between shallow (buoy) and control plates indicates greater mortality among the juvenile corals in shallow water ( $p<0.001$ in both cases). Experiment \# 1 did not have enough corals to justify statistical testing, but the trend was the same.

Although run side-by-side with Experiment \#2, Experiment \# 3 showed lower mortality rates. This could be due to genetic differences among the adult populations (parent corals in Experiment \#3 were on Tanner Bank, while those in Experiment \# 2 were from Quast Rock or the kelp bed at Pt. Loma), to different conditions at the time of settlement and metamorphosis (in the field of Experiment \#3, in the laboratory in Experiment \# 2), or to the shorter transplant period ( 3 instead of $41 / 2$ months).

Shortly after undergoing metamorphosis, juveniles of Balanophyllia elegans are $2.0-3.0 \mathrm{~mm}$ in calyx diameter. The juvenile transplanted corals reported in Table 2 were newly metamorphosed corals and were in this size range. On 2 other plates, however, which had been left in the kelp bed for 4 years in order to collect recruits of $B$. elegans, there was a greater range of sizes (ages) of small corals. Some had recently metamorphosed, while others were known to be several years old. When these plates were placed in shallow water on the buoy from 15 June-20 September 1977, the distribu- tion of mortalities by size was striking. All of the mortalities were among the smaller corals (Fig. 6). The significance of this effect may be tested statistically by comparing the number of mortalities occurring on either side of the median size, $3.0 \mathrm{~mm}$. The result of this test is significant ( $p<0.005$ by $G$-test of independence: Sokal and Rohlf, 1969). Whatever was the cause of death, therefore, affected the smaller corals more severely than the larger ones.
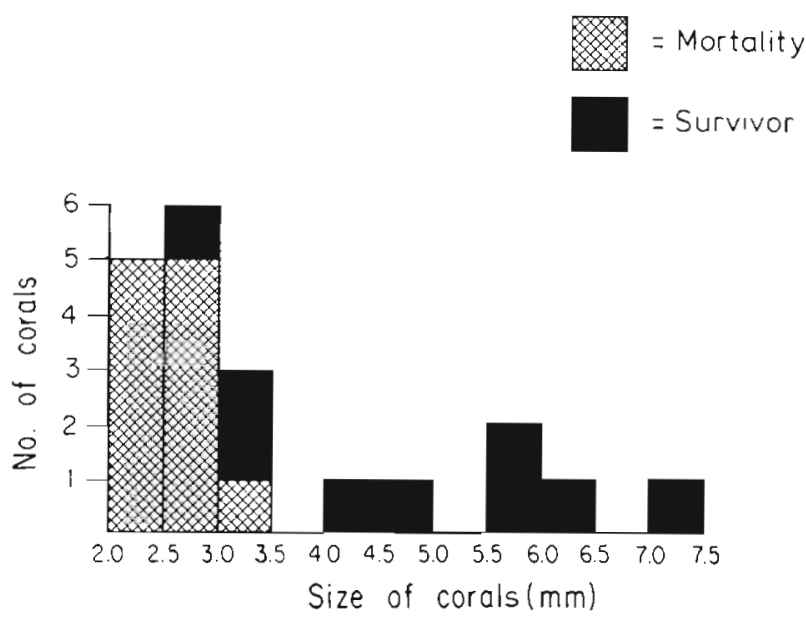

Fig. 6. Balanophyllia elegans. Distribution of mortalities (cross-hatched bars) and survivors (solid bars) by size (calyx diameter) among young corals placed in shallow water Corals $2-3 \mathrm{~mm}$ in size are less than 1 year old; the largest corals (> $5.5 \mathrm{~mm}$ ) are 3 years old

The hypothesis that juvenile Balanophyllia elegans are unable to survive in shallow water was consequently upheld. The results presented in Table 2 and Fig. 6 show that the first year after metamorphosis is the most critical stage in the life history of $B$. elegans for survival in shallow water. 


\section{DISCUSSION}

While the processes of reproduction are frequently viewed as the most sensitive to environmental stresses (e.g. Thorson, 1950; Hall, 1964; Andronikov, 1975), the experiments reported here showed the most sensitive life history stage of the solitary coral Balanophyllia elegans was the juvenile. Direct transplantation revealed that adults can survive and reproduce in surface water, but that growth is slow. The growth rate could be increased by supplemental feeding, both in surfacetemperature and chilled water. Planulae settled on plates in surface water in the laboratory, suggesting that larval settlement and metamorphosis could take place in shallow water. It can be concluded, therefore, that $B$. elegans is excluded from shallow water $(<10 \mathrm{~m}$ depth, Fig. 3) by a failure of juvenile survival (and, possibly, adult growth) rather than by a failure of reproduction, embryological development, or larval settlement.

The tendency to occur at greater depths (or to have the upper bathymetric limit at greater depths) at the equatorial end of a species' range, as in Figure 1, is apparently widespread among marine organisms. Ekman (1953) has termed this tendency southern or equatorial submergence. Gislén (1944) documented the phenomenon along the California coast, showing that there was a clear tendency among littoral organisms to occur at lower levels to the south. Since this submergence parallels the equatorial depression of oceanic isotherms, equatorial submergence has been assumed to be a response to temperature. Temperate or boreal organisms are assumed to be unable to live in the warmer surface waters nearer the equator and must 'retreat' to deeper water. The submergence of Balanophyllia elegans takes place in the vicinity of Pt. Conception where there is a pronounced change in mean water temperature (Fig. 1).

The biogeographical significance of Pt. Conception for Balanophyllia elegans is well supported by studies on a variety of other organisms. Recent examples include studies which find Pt. Conception an important faunal boundary for barnacles (Newman, in press), fish (Horn and Allen, 1978), isopods (Brusca and Wallerstein, in press), and a newly discovered sibling species of limpet (Murphy, 1978). Valentine (1966) defined biogeographical provinces based on distribution records of over 2000 species of molluscs and compared his results with previous schemes. Pt.Conception is recognized as the boundary between the Oregonian and Californian provinces. The subtidal distribution of $B$. elegans fits into this biogeographical scheme, since its submergence coincides approximately with this same faunal boundary,

Temperature has long been assumed to cause large- scale patterns of biogeographical zonation (Dana, 1853; Orton, 1920; Hutchins, 1947; Hedgpeth, 1957; Hayden and Dolan, 1976), including the subtidal zonation (equatorial submergence) considered in this paper. Ekman (1953, p. 249) states, 'Submergence is simply a consequence of the animal's reaction to temperature'. Evidence for the importance of temperature in controlling marine distributions comes from (1) the correlation of distribution with temperature anomalies (Hubbs, 1948; Dawson, 1951), (2) the correlation of range end-points with areas of strong thermal gradients, as at Pt. Conception (Valentine, 1966), and (3) the correlation of lethal thermal limits with distribution among several related species (Southward, 1958; Vernberg and Vernberg, 1970; Andronikov, 1975; but see also Wilson, 1978). For pertinent reviews consult 'Marine Ecology', Volume I: Brett (1970), Gessner (1970), Kinne (1970). There is little doubt that temperature plays a major role in determining the distributions of marine organisms.

It is recognized that temperature need not be directly lethal to be a critical determinant of distribution, since sub-lethal effects are probably more important than direct mortality in nature (e.g. Southward, 1958). Extreme temperature (or other stresses) may determine distribution indirectly by influencing rate of feeding, growth, escape from predators, fecundity, or competitive vigor. For example, Pattee et al. (1973) concluded that a temperature-mediated competition best explained the observed triclad distribution along an altitude gradient. Moreover, Bayne et al. (1975) found that temperature and food stress in adult Mytilus edulis affected not only fecundity but subsequent larval development. Thus, for at least some species, lethal thermal limits determined in the laboratory are difficult to relate directly as the limiting factor of a species' distribution. Not only are there many subtle effects that temperature could have, but also there is no single critical thermal temperature for a given species, since lethal limits may vary with stage in the life history, with physiological condition, and with length and type of exposure.

I do not know the cause or causes of juvenile mortality and slow adult growth in Balanophyllia elegans transplanted to a buoy in shallow water. Possible factors include temperature, food supply, light, water movement, competition and predation. The greater susceptibility of juveniles to various mortality factors may be related to the higher growth rates for juveniles than adults (Gerrodette, 1979). Experimental artifacts are also possible. Since few corals were recovered from transplant plates placed on the bottom in shallow water, the results are based on the survival or mortality of corals in shallow water on subsurface buoys. Corals on a buoy may survive differently than corals on the 
bottom in shallow water. For example, Weaver (1978) found that survival of juvenile $B$. elegans on plates $1.5 \mathrm{~m}$ above the bottom was much better than on plates placed directly on the bottom.

Temperature, predation and competition have all been shown to be important for coral zonation and distribution. Glynn and Stewart (1973) found from transplant experiments that low temperature was important in determining the distribution of coral reefs in the Pearl Islands in the Gulf of Panama by affecting the growth rate of adult corals. Growth rates of adult $\mathrm{Ba}$ lanophyllia elegans transplanted into shallow water also declined markedly in this study, and this might be sufficient to exclude the population from shallow water. Neudecker (1977) performed other transplant experiments with reef corals and established that predatory fish excluded certain coral species from the outer reef. Birkeland (1977) found that survival of coral recruits in tropical waters depended on competition from other sessile benthic organisms mediated by nutrients and light. Nutrients and light were beneficial to coral growth but were beneficial to faster-growing fouling species even more.

The possible role of biological factors in determining biogeographical boundaries has not received sufficient emphasis. Recently, however, Brusca and Wallerstein (in press) have speculated that biotic factors, not temperature, regulate the southern limit of distribution of some shallow-water idoteid isopods, although their supporting data are still preliminary. Newman (in press) has shown that certain species of barnacles are endemic to the region of rapid faunal change centered on Pt. Conception known as the Californian Transition Zone, and argued that their occurrence within the zone is favored by an incomplete utilization of resources in the area of overlap between the Oregonian and Californian provincial communities.

Correlations of distribution with temperature (or other parameters) do not, of course, prove that temperature is a factor directly limiting the distribution of a species. Temperature potentially affects all aspects of physiology and behavior. Moreover, biological interactions capable of limiting distribution (competition, disease, or predation, for example) may themselves be dependent on temperature, and their role in setting the distributional limits of many species may be greater than has previously been appreciated.

Acknowledgements. This research was assisted by a Sea Grant Traineeship, NSF Grant DES75-08661 to Paul K. Dayton, a Sigma Xi Grant-in-Aid of Research, and a cruise sponsored by the University of California Ship Fund. I thank Marie McGee und David Zeh for helping with the weighing and measuring of transplanted corals, Jim Morin and Noël Davis for the use of their dive logs, and Science Applications, Inc for the opportunity to collect juvenile corals on Tanner Bank.
The manuscript has benefitted from critical readings by William Newman, Paul Dayton, John Pearse, G. David Lange. and Nicholas Holland.

\section{LITERATURE CITED}

Andronikov, V B. (1975). Heat resistance of gametes of marine invertebrates in relation to temperature conditions under which the species exist. Mar. Biol., 30, 1-11

Arthur, R. S. (1954). Oscillations in sea temperature at Scripps and Oceanside piers. Deep Sea Res., 2, 107-121.

Bayne, B. L., Gabbott, P. A. and Widdows, J. (1975). Some effects of stress in the adult on the egg and larvae of. Mytilus edulis L. J. mar. biol. Ass. U. K., 55, 675-689.

Birkeland, C. (1977). The importance of rate of biomass accumulation in early successional stages of benthic communities to the survival of coral recruits. In D. L. Taylor (Ed.), Proc. 3rd Int. Symp. Coral Reefs, Vol. 1, School of Marine and Atmospheric Sciences, University of Miami, Miami. pp. 15-21.

Brett, J. R. (1970). Temperature: animals: fishes. In O. Kinne (Ed.), Marine Ecology, Vol. I, Environmental Factors, Part 1 Wiley, London. pp. 515-560.

Brusca, R. C. and Wallerstein, B. R. (in press). Zoogeographic patterns of idoteid isopods in the Northeast Pacific, with a review of shallow water zoogeography of the area. In Symposium on the Composition and Evolution of Crustaceans in the Cold and Temperate Waters of the World Ocean. U.S.-U.S.S.R. Cooperative Program, Duke University Marine Laboratory, Beaufort, N.C., Oct. 20-22, 1978.

Clarke, T A. (1968). Territorial behavior and population dynamics of the garibaldi, Hypsypops rubicunda (Girard), Pisces: Pomacentridae. Ph. D. thesis, Scripps Institution of Oceanography, University of California, San Diego.

Dana, J. D. (1853). On the geographical distribution of Crustacea. United States Exploring Expedition during the years 1838-1842, under the command of Charles Wilkes, U.S.N., 13, $1451-1592$

Dawson, E. Y (1951). A further study of upwelling and associated vegetation along Pacific Baja California, Mexico. $J$. mar. Res., 10, 39-58.

Defant, A. (1950). Reality and illusion in oceanographic surveys. J. Mar. Res., 9, 120-138.

Durham, J. W. (1947). Corals from the Gulf of California and the North Pacific coast of America. Mem geol. Soc. Am., $20,1-68$.

Durham, J. W. and Bamard, J. L. (1952). Stony corals of the Eastern Pacific collected by the Velero III and Velero IV. Allan Hancock Pacif. Exped, 16, 1-110

Ekman, S. (1953). Zoogeography of the Sea, Sidgwick and Jackson, London.

Gerrodette. I (1979). Ecological studies of two temperate solitary corals. Ph. D. thesis, Scripps Institution of Oceanography, University of California. San Diego.

Gessner, F. (1970). Temperature: plants. In O. Kinne (Ed.). Marine Ecology, Vol. I, Environmental Factors, Part 1. Wiley, London. pp. 363-406.

Gislén, T (1944). Regional conditions of the Pacific coast of America and their significance for the development of marine life. Acta Univ. lund. (ser 2), 40, 1-91.

Glynn, P. W and Stewart, R. H. (1973). Distribution of coral reefs in the Pearl Islands (Gulf of Panamá) in relation to thermal conditions. Limnol. Oceanogr., 18, 367-379. 
Grigg. R. W (1970). Ecology and population dynamics of the gorgonians, Muricea californica and Muricea fruticosa. Ph. D. thesis, Scripps Institution of Oceanography, University of California, San Diego.

Hall, C. A., Jr. (1964). Shallow-water marine climates and molluscan provinces. Ecology, 45, 226-234.

Hayden, B. P. and Dolan, R. (1976). Coastal marine fauna and marine climates of the Americas. J. Biogeog., 3, 71-81

Hedgpeth, J. W (1957). Marine biogeography. Mem. geol. Soc. Am., 67 (Vol. 1), 359-382.

Horn, M. H. and Allen, L. G. (1978). A distributional analysis of California coastal marine fishes. J. Biogeog., 5, 23-42.

Hubbs, C. L. (1948). Changes in the fish fauna of western North America correlated with changes in ocean temperature. J. mar. Res., 7, 459-482.

Hutchins, L. W. (1947). The bases for temperature zonation in geographical distribution. Ecol. Monogr., 17, 325-335.

Kozloff, E. N. (1973). Seashore Life of Puget Sound, the Strait of Georgia, and the San Juan Archipelago, University of Washington Press, Seattle

Kinne, O. (1970). Temperature: animals: invertebrates. In O. Kinne (Ed.), Marine Ecology, Vol. I, Environmental Factors, Part 1 Wiley, London. pp. 407-514.

Leipper, D. F. (1950). Sea temperature variations associated with tidal currents in stratified shallow water over an irregular bottom. Ph. D. thesis, Scripps Institution of Oceanography, University of California, Los Angeles.

Murphy, P. G. (1978). Collisella austrodigitalis sp. nov.: A sibling species of limpet (Acmaeidae) discovered by electrophoresis. Biol Bull mar biol. Lab. Woods Hole, 155, 193-206.

National Ocean Survey (1970). Surface Water Temperature and Density. Pacific Coast, North and South America and Pacific Ocean Islands, 3rd ed., U.S. Government Printing Office, Washington, D.C.

Neudecker, S. (1977). Transplant experiments to test the effect of fish grazing on coral distribution. In D. L. Taylor (Ed.), Proc 3rd Int. Symp. Coral Reefs, Vol. 1. School of Marine and Atmospheric Sciences, University of Miami. pp. 317-323.

Newman, W. A. (in press). Californian Transition Zone: Significance of short range endemics. In J. Gray and A. Boucot (Eds), Historical Biogeography, Plate Tectonics, and the Changing Environment. Oregon State University Press, Corvallis. Ch. 32 .

Orton, J. H. (1920). Sea-temperature, breeding, and distribution in marine animals. J. mar, biol. Ass. U.K., 12, 339-366.

Pattee, E., Lascombe, C. and Delolme, R. (1973). Effects of temperature on the distribution of turbellarian triclads. In W Wieser (Ed.), Effects of Temperature on Ectothermic Organisms. Springer-Verlag, Berlin. pp. 201-207.

Quast, J. C. (1971). Some physical aspects of the inshore environment, particularly as it affects kelp bed fishes Nova Hedwigia, 32, 229-240.

Scanland, T. B. (1971). Effects of predation on epifaunal assemblages in a submarine canyon. Ph. D. thesis, Scripps Institution of Oceanography, University of California, San Diego.

SIO Reference $78-5$ (1978). Surface water temperatures at shore stations, U.S. West Coast, 1975-1976. Scripps Institution of Oceanography, University of California, San Diego.

SIO Reference 78-16 (1978). Surface water temperatures at shore stations, U.S. West Coast, 1977. Scripps Institution of Oceanography, University of California, San Diego.

Smith, R. I. and Carlton, J. T (Eds) (1975). Light's Manual: Intertidal Invertebrates of the Central California Coast, 3rd ed., University of California Press, Berkeley.

Sokal, R. R. and Rohlf, F. J. (1969). Biometry, W. H. Freeman, San Francisco.

Southward, A. J. (1958). Note on the temperature tolerances of some intertidal animals in relation to environmental temperatures and geographical distribution J. mar. Biol. Ass. U.K., 37, 49-66.

Thorson, G. (1950). Reproduction and larval ecology of marine bottom invertebrates. Biol. Rev, 25, 1-45.

Turner, C. H., Ebert, E. E. and Given, R. R. (1968). The marine environment offshore from Point Loma, San Diego County. Fish. Bull. Calif., 140,1-85.

Tutschulte, T C. (1976). The comparative ecology of three sympatric abalones. Ph. D. thesis, Scripps Institution of Oceanography, University of California, San Diego.

Valentine, J. W. (1966). Numerical analysis of marine molluscan ranges on the extratropical northeastern Pacific shelf. Limnol. Oceanogr., 11, 198-211.

Vernberg, F. J. and Vernberg, W. B. (1970). Lethal limits and the zoogeography of the faunal assemblages of coastal Carolina waters. Mar. Biol., 6, 26-32.

Weaver, A. M. (1978). Aspects of the effects of particulate matter on the ecology of a kelp forest (Macrocystis pyrifera [L.] C. A. Agardh) near a small domestic sewer outfall. Ph. D. thesis, Department of Biological Sciences, Stanford University, Palo Alto, Calif

Wilson, J. G. (1978). Upper temperature tolerances of Tellina tenuis and T fabula. Mar. Biol., 45, 123-128.

Winant, C. D. (1979). Coastal current observations. Rev. Geophys. Space Physics, 17, 89-98.

Winant, C. D. and Olson, J. R. (1976). The vertical structure of coastal currents. Deep-Sea Res., 23, 925-936.

Wolfson, A., Lewbel, G., Littler, M. M. and Gerrodette, T. (1978). Biological features of the subtidal community at South Tanner Bank. Southern California Baseline Study, Year Two Final Report, Vol. III, Report 1.1.17, U.S. Bureau of Land Management. 